\title{
RANCANG BANGUN SISTEM SAMPLING AIR TENAGA SURYA GUNA MENDUKUNG TEKNOLOGI ONLINE MONITORING KUALITAS AIR DI REMOTE AREA
}

\author{
Priska Alfatri Hendrayanto, Heru Dwi Wahjono, Robertus Haryoto Indriatmoko, Yosep Widi \\ Nugraha, Irwan Kustianto, Muhamad Miranda \\ Pusat Teknologi Lingkungan, Badan Pengkajian dan Penerapan Teknologi \\ Gedung Geostech 820, Kawasan Puspiptek Serpong, Tangerang Selatan, Banten, 15314, Indonesia \\ Email: priska.alfatri@bppt.go.id, heru.dwi@bppt.go.id, robertus.haryoto@bppt.go.id, yosep.widi@bppt.go.id, \\ irwan.kustianto@bppt.go.id
}

\begin{abstract}
ABSTRAK
Masalah pencemaran kualitas air terjadi di beberapa daerah terpencil di Indonesia. Pencemaran yang terjadi umumnya bersumber pada banyaknya sedimentasi yang berasal dari wilayah hulu dengan banyaknya penebangan hutan dan pembukaan lahan pertanian secara liar oleh masyarakat. Untuk mengendalikan pencemaran yang terjadi di remote area ini, perlu dipantau menggunakan teknologi telemeteri online monitoring kualitas air. Adanya keterbatasan sumber energi listrik di remote area menyebabkan perlunya dilakukan inovasi sumber listrik menggunakan tenaga surya untuk mengoperasikan sistem peralatan telemetri. Tulisan ini membahas pengembangan sistem sampling pemantauan kualitas air yang dapat dioperasikan menggunakan sistem pompa 12VDC yang digerakkan dengan sumber listrik tenaga surya. Penelitian diasumsikan untuk memantau kualitas air sungai di remote area dengan sumber air sungai di kedalaman 8 12 meter. Sistem sampling yang dikembangkan adalah sistem bertingkat (cascade) menggunakan pompa 24VDC. Hasil penelitian menunjukkan bahwa untuk memompa air sungai dengan posisi lereng yang curam perlu dibuat sistem sampling bertingkat menggunakan pompa submersibel 24VDC.
\end{abstract}

Kata kunci: pencemaran air, kualitas air, sistem pemompaan, sistem sampel, tenaga surya

\section{DESIGN OF SOLAR POWERED WATER SAMPLING SYSTEM TO SUPPORT WATER QUALITY ONLINE MONITORING TECHNOLOGY IN REMOTE AREA}

\author{
Priska Alfatri Hendrayanto, Heru Dwi Wahjono, Robertus Haryoto Indriatmoko, Yosep Wid \\ Nugraha, Irwan Kustianto, Muhamad Miranda \\ Center for Environmental Technology, Agency for Assessment and Application of Technology \\ Geostech Building 820, Puspiptek Area Serpong, South Tangerang, Banten, 15314, Indonesia \\ Email: priska.alfatri@bppt.go.id, heru.dwi@bppt.go.id, robertus.haryoto@bppt.go.id, yosep.widi@bppt.go.id, \\ irwan.kustianto@bppt.go.id
}

\begin{abstract}
The problem of water quality pollution occurs in several remote areas in Indonesia. Pollution that occurs generally comes from the amount of sedimentation originating from the upstream area with a lot of deforestation and illegal agricultural land clearing by the community. To control pollution that occurs in remote areas, it is necessary to monitor also using online water quality monitoring telemetry technology. The limited source of electrical energy in the remote area to operate the telemetry equipment system is a problem. Therefore it is necessary to innovate electricity sources using solar power to run the equipment. This paper discusses the development of a water quality monitoring sampling system that can be operated using a 12VDC pump system that is driven by a solar power source. The study was assumed to monitor river water quality in remote areas with river water sources at a depth of $8 \sim 12$ meters. The sampling system developed is a cascade system using a 24VDC pump. The results showed that to pump river water with a steep slope position it was necessary to make a multilevel sampling system using a 24VDC submersible pump.
\end{abstract}

Keywords: water pollution, water quality, pumping system, sampling system, solar cell 


\section{PENDAHULUAN}

\subsection{Latar Belakang}

Semakin pesatnya pertumbuhan penduduk dan pembangunan industry di kota maupun di daerah memberikan dampak yang cukup serius terhadap pencemaran air. Sumber pencemar tersebut berasal dari limbah domestic maupun industry yang ada di daerah aliran sungai.

Salah satu upaya yang dapat dilakukan untuk mengendalikan pencemaran air adalah dengan menerapkan pemantauan kualitas air baik yang akan masuk ke sungai atau di lokasi aliran sungai. Pemantauan ini perlu dilakukan secara terus menerus dengan cara menganalisis kualitas air yang masuk atau yang berada pada wilayah perkotaan atau daerah aliran sungai. Bila ada polutan ekstrim yang mencemari air dalam suatu waktu tertentu, pemerintah atau pihak yang berwenang dapat mengetahuinya dengan segera sehingga dapat melakukan tindakan pengendalian pencemaran dengan cepat.

Dalam melakukan pemantauan kualitas air, telah dilakukan upaya yang masih bersifat konvensional, yaitu dengan mengambil sampel di lokasi pemantauan, membawa ke laboratorium dan melakukan analisa. Namun cara konvensional ini memiliki beberapa kendala diantaranya adalah jarak dari lokasi ke laboratorium yang cukup jauh, kemacetan lalu lintas, dan juga resiko bahaya saat pengambilan sampel langsung di lokasi sungai. Kendala lain yang cukup signifikan yakni biaya sampel yang cukup mahal, sehingga untuk melakukan pemantauan kualitas air secara rutin di banyak titik di aliran sungai memerlukan anggaran yang sangat besar.

Untuk mengatasi kendala tersebut, dengan menerapkan teknologi online monitoring kualitas air di beberapa lokasi pemantauan baik di lokasi sumber pencemar maupun di beberapa lokasi tertentu. Lembaga riset dan penerapan teknologi di bawah Kementerian Ristek dan Teknologi yang telah mengembangkan sistem pemantauan kualitas air secara online adalah Pusat Teknologi Lingkungan - Badan Pengkajian dan Penerapan Teknologi. Berbagai teknologi dan metode sudah banyak dikembangkan dalam skala prototipe oleh sistem ini. KLHK telah bekerjasama dengan BPPT untuk melakukan penerapan online monitoring kualitas air di beberapa sungai di Indonesia yang telah dituangkan pada MoU No. 32/KB/BPPTKEMENLH/08/2014 dan No. 07/Dep.II/LH/08/2014.

Di lokasi pengambilan sampel beda ketinggian antara sungai dan daratan, maka untuk mengalirkan sampel air sungai menggunakan bantuan pompa air. Namun adanya keterbatasan sumber energi listrik di remote are menyebabkan perlunya dilakukan inovasi sumber listrik untuk menggerakkan pompa air sampling. Beberapa sumber energi terbarukan dapat digunakan untuk pompa air. Energi matahari telah terbukti memiliki hubungan langsung dengan ketersediaan air (Whajono, 2006). Beberapa lokasi di mana jaringan listrik tidak terpenuhi memiliki intensitas cahaya matahari yang tinggi. Panel photovoltaic menggunakan energi matahari dan secara langsung menghasilkan listrik yang dapat digunakan untuk menyalakan pompa air.

Selama beberapa tahun terakhir, para peneliti telah memfokuskan pada pengembangan sistem pompa air bertenaga surya yang efisien. Dengan meningkatnya kesadaran tentang krisis energi yang muncul di dunia, sistem pompa air bertenaga surya (SPWPS) telah menjadi fokus nyata minat para peneliti selama beberapa dekade.

\subsection{Tujuan dan Sasaran}

Tujuan dari penelitian ini adalah untuk merancang desain dan menghitung kebutuhan solar cell dan baterai pada sistem sampling air tenaga surya. Sasaran dari penelitian ini adalah terciptanya peralatan sistem sampling air tenaga surya. Hasil penelitian ini diharapkan dapat menjadi bahan pertimbangan dalam pembuatan teknologi online monitoring kualitas air untuk pemantauan kualitas air secara realtime dilengkapi dengan sistem sampling air tenaga surya.

\section{LINGKUP DAN METODOLOGI KEGIATAN}

Lingkup kegiatan rancang bangun sistem sampling air tenaga surya untuk pemantauan kualitas air meliputi :

- Perhitungan total daya setiap peralatan yang digunakan pada sistem sampling air.

- Perhitungan total daya selama waktu tertentu sesuai kebutuhan pengguna.

- Perhitungan kebutuhan solar panel, baterai dan solar charge controller dan pemilihan jenisnya.

- Desain konsep dan desain 3D peralatan sistem sampling air tenaga surya.

- Desain 3D teknologi telemeteri online monitoring kualitas air di remote area yang tidak memiliki pasokan listrik. 


\section{HASIL DAN PEMBAHASAN}

3.1 Peralatan sistem sampling air tenaga surya

Dalam perancangan system sampling air sungai menggunakan tenaga surya komponen yang diperlukan adalah sebagai berikut :

a. Kerangka dan skeed system/ bangunan Kerangka bangunan didesain berbentuk menara dengan tinggi 3 meter dengan tujuan untuk memanfaatkan sistem gravitasi bumi agar dapat mengalirkan air ke dalam tangki sampling air.

b. Panel Surya 100 WP

Panel surya 100 WP digunakan untuk menyerap energi panas matahari dan mengubahnya menjadi energi listrik yang akan digunakan untuk mengisi baterai/ACCU kapasitas 100 Ah 12 Volt.

c. Baterai/ACCU 100 Ah 12 Volt Baterai/ACCU dengan daya 100 Ah 12 Volt digunakan untuk menyimpan energi listrik dari Panel Surya dan menggunakan energi listrik tersebut untuk menggerakan pompa air DC 12 Volt.

d. Submersible Pump DC 12 Volt

Pompa celup DC 12 Volt digunakan untuk menghisap air dan mengalirinya kedalam tangki-tangki air.

e. Tangki Air \pm 100 liter

Tangki air digunakan untuk menampung pengambilan sampel air.

f. Floating Switch

Floating Switch berfungsi untuk mengatur selenoid valve dalam membuka dan menutup aliran air.

g. Selenoid Valve DC 12 Volt 1 inchi Selenoid Valve digunakan untuk membuka dan menutup aliran air dengan menggunakan energi listrik.

h. Perpipaan atau Selang Air

Perpipaan atau selang air digunakan sebagai media agar air bisa mengalir.

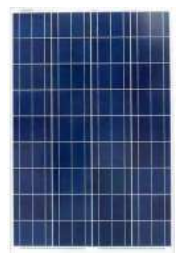

(a)

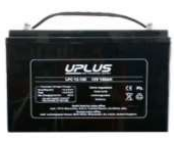

(b)

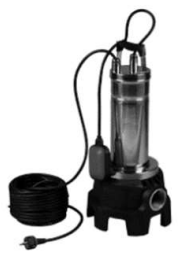

(c)

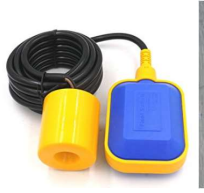

(d)

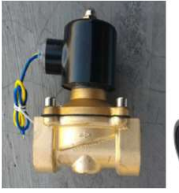

(e)

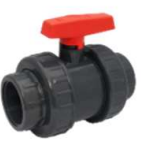

(f)
Gambar 1. Peralatan sistem sampling air tenaga surya

(a) Solar cell; (b) Baterai/ACCU; (c)

Submersible pump; (d) Floating pump; (e) Solenoid valve; (f) Ball valve

\subsection{Perhitungan total daya kebutuhan sistem sampling tenaga surya}

Berdasarkan koordinasi awal yang dibuat untuk monitoring kualitas air di remote area diputuskan menggunakan 2 buah pompa DC $12 \mathrm{~V} 180 \mathrm{~W}$ dengan flow rate sebesar 50L/Menit dan menggunakan 2 solenoid valve untuk mengatur flow dari air sampling. Pengambilan sampling dilakukan selama $24 \mathrm{kali} / \mathrm{hari}$ dengan besar bak penampungan yang berkapasitas $100 \mathrm{~L}$.

Tabel 1. Perhitungan daya kelistrikan sistem sampling air tenaga surya

\begin{tabular}{|c|c|c|c|c|}
\hline List Alat & Jumlah & $\begin{array}{c}\text { Power } \\
\text { (W) }\end{array}$ & $\begin{array}{c}\text { Estimasi } \\
\text { pemakaian } \\
\text { per hari }\end{array}$ & $\begin{array}{l}\text { Total } \\
\text { Power } \\
\text { / hari }\end{array}$ \\
\hline $\begin{array}{l}\text { Pompa } \\
12 \mathrm{~V} \\
\text { 50L/Menit }\end{array}$ & 2 & 180 & $\begin{array}{l}5 \text { menit } \\
\text { selama } 24 \\
\text { kali }\end{array}$ & 720 \\
\hline \multirow[t]{3}{*}{$\begin{array}{l}\text { Solenoid } \\
\text { Valve } \\
12 \mathrm{~V} 1 \\
\text { Inch }\end{array}$} & \multirow[t]{3}{*}{2} & \multirow[t]{3}{*}{10} & $\begin{array}{l}10 \text { menit } \\
\text { selama } 24 \\
\text { kali }\end{array}$ & 80 \\
\hline & & & Total & 800 \\
\hline & & & $\begin{array}{l}\text { Losses } \\
20 \%\end{array}$ & 960 \\
\hline
\end{tabular}

Solar panel yang digunakan mempunyai spesifikasi 12V 100WP yaitu solar panel dapat menghasilkan listrik sebesar $100 \mathrm{~W} /$ jam ketika kondisi peak atau terkena sinar matahari secara sempurna. Jika rata-rata per hari diperkirakan kondisi peak selama 4 jam per hari maka total power yang dihasilkan solar panel adalah sebesar $400 \mathrm{~W}$. Dari perhitungan tersebut dapat dihitung kebutuhan solar panel sebagai berikut :

- Total power yang dibutuhkan per hari $960 \mathrm{~W} / 400 \mathrm{~W}=2,4$ Pcs (dibulatkan menjadi 3 Pcs)

Battery yang digunakan mempunyai tegangan $12 \mathrm{~V}$ dan Arus sebesar $100 \mathrm{Ah}$.

Maka kebutuhan untuk baterai dengan cadangan untuk 1 hari (kondisi tidak ada 
cahaya selama 1 hari) adalah sebagai berikut :

- $\quad$ Total Power yang dibutuhkan per hari $\mathrm{x}$ 2 / Power battery

$(960 \times 2) /(12 \mathrm{~V} \times 100 \mathrm{Ah})=1,6 \mathrm{Pcs}$ (dibulatkan menjadi 2 Pcs)

Untuk kebutuhan solar charger controller dihitung dari tegangan dan besar arus yang melewati pada rotary yaitu pada solar panel (3 pcs) arus yang lewat selama 1 jam sebesar $25 \mathrm{~A}(300 \mathrm{~W} / 12 \mathrm{~V})$ dan arus pada beban selama 1 jam sebesar 31,7 A (380 W / 12V). Jadi untuk solar charger controller dibutuhkan dengan spesifikasi 12 $\mathrm{V} 30 \mathrm{~A}$.

\subsection{Desain Sistem Sampling Air Tenaga Surya}

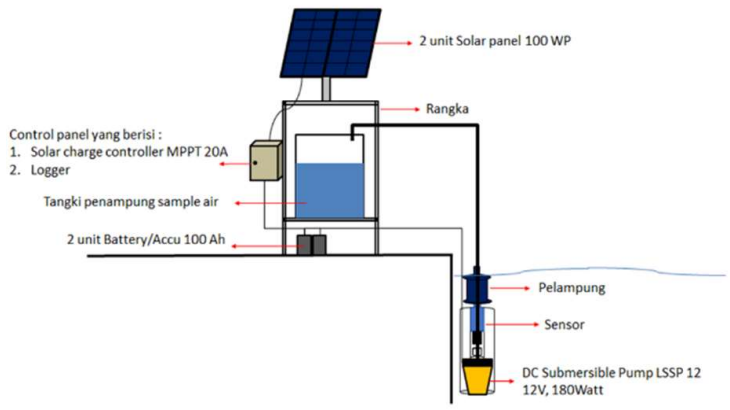

Gambar 2. Sistem pengukuran dan pengambilan sampel

Sistem kerja dari unit sampling air sungai menggunakan tenaga matahari adalah sebagai berikut :

a. Pada awalnya air dalam tangki sensor (tangki 2) dalam keadaan terisi sehingga sensor tetap dalam keadaan terdam air.

b. Posisi selenoid pada tangki sensor tertutup/ Secara normal tertutup.

c. Air baku pada tangki di atas menara (tangki 1) juga dalam keadaan penuh.

d. Pada saat pengukuran akan dimulai maka sistem loger memerintahkan untuk membuka selenoid dalam tangki 2, akibatnya air dalam tangki 1 akan mengalir secara grafitasi masuk ke tangki 2 sampai over flow.

e. Waktu yang dibutuhkan untuk membuka selenoid dirancang 2 kali waktu tinggal air yang ada dalam tangki 1, alasannya supaya air yang masuk ke tangki 2 adalah air baru yan siap disampling.

f. Setelah waktu yang dibutuhkan untuk membuka selenoid terpenuhi (min dua kali waktu tinggal) maka selenoid akan menutup off. g. Adanya sistem selenoid yang terbuka maka air dalam tangki 1 akan turun elevasinya karena berpindah dari tangki 1 ke tangki 2, maka radar akan aktif dan membuat sistwm switch dalam pompa celup akan aktif sehingga air akan terpoma keatas, mengisi ke tangki antara setelah levelnya terpenuhi maka pompa celup dalam tangki antara akan aktif dan memompa air naik ke tangki 1 , air dalam tangki 1 akan naik sehingga akan mengaktifkan sistem radar untuk memerintrahkan pompa celup di dalam sungai akan stop/off yang kemudian akan diikuti dengan berhentinya kerja pompa antara.

h. Pengukuran kualitas air dimulai/dapat dimulai ketika logger sudah selesai memerintahkan selenoid untuk off/menutup.

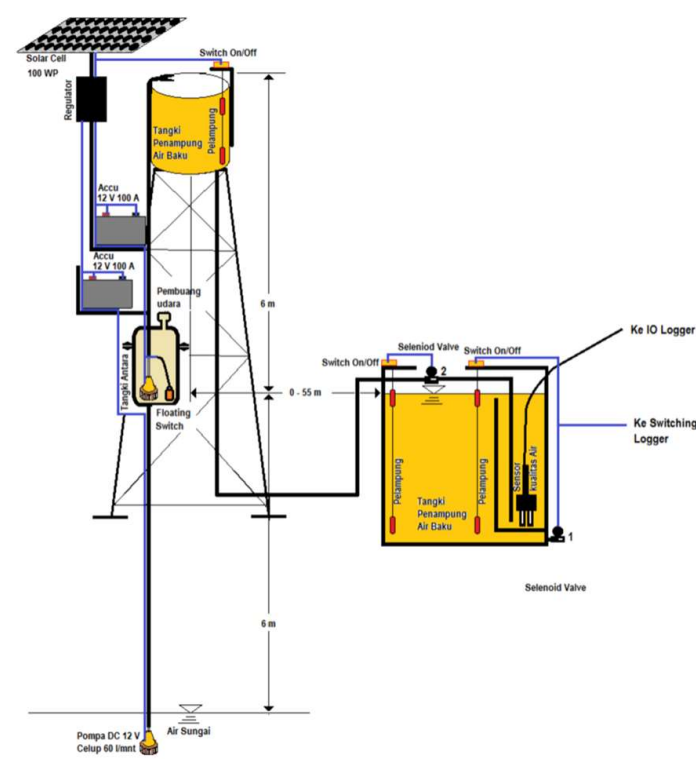

Gambar 3. Rancangan pengambilan sampel air monitoring kualitas air sungai

Perancangan desain untuk pengambilan sampel air sungai dengan tenaga surya dibutuhkan untuk memenuhi kebutuhan unit monitoring yang terpasang didaerah yang tidak tersedia sumber listrik. Sumber listrik ini diperlukan untuk memompa air sungai yang akan diukur kualitasnya pada alat sistem monitoring kualitas air sungai. Perancangan ini didesain sedemikian rupa menyesuaikan dengan ketersediaan pompa yang ada dipasaran. Pompa yang tersedia saat ini adalah tipe open impeler kapasitas 60 liter/menit, voltase 12 Volt, daya dorong maksimal 6 meter. Dengan perkiraan tinggi permukaan air ratarata 6 meter dari dari permukaan tanah maka 
penempatan tangki air baku perlu lebih tinggi lagi sebesar 6 meter sehingga total jarak dari permukaan air sampai air baku menjadi 12 meter, penambahan tinggi ini dilakukan agar proses transfer air sampel ke tangki monitoring dapat dilakukan secara gravitasi.

Untuk melengkapi keterangan gambar 4 diatas dapat dideskripsikan sebagai berikut :

1. Pompa air sungai atau pompa umpan dikontrol oleh pelampung radar (floating switch) yang terdapat pada tangki umpan, pompa ini hidup apabila air pada tangki umpan berada dibawah level bawah pelampung radar.

2. Pompa air sungai akan mengisi tangki antara, apabila tangki ini sudah penuh maka pompa antara akan memompa airnya ke tangki umpan. Pompa ini juga dikendalikan oleh pelampung radar.

3. Selenoid valve akan bekerja setelah mendapat instruksi dari logger sensor, jika solenoid terbuka maka tangki umpan akan mentranfer air sampel yang segar ke tangki monitoring. Tangki monitoring ini terdiri dari 2 ruangan yang mana ruangan terdapat sesnsor harus selalu terisi air. Sedangkan limpasan air sisa yang tergenang akan terbuang melalui ballvalve.

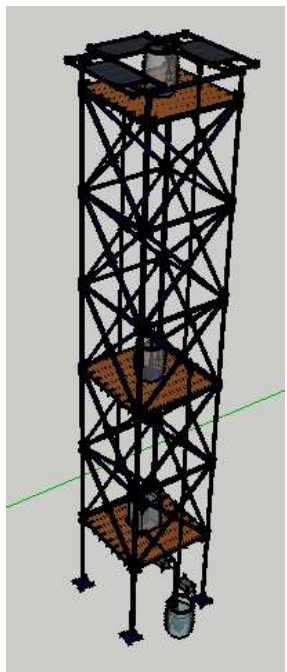

Gambar 4. Desain Menara Sampling

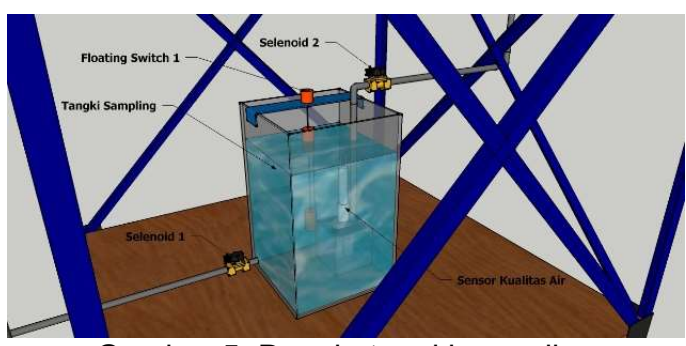

Gambar 5. Desain tangki sampling

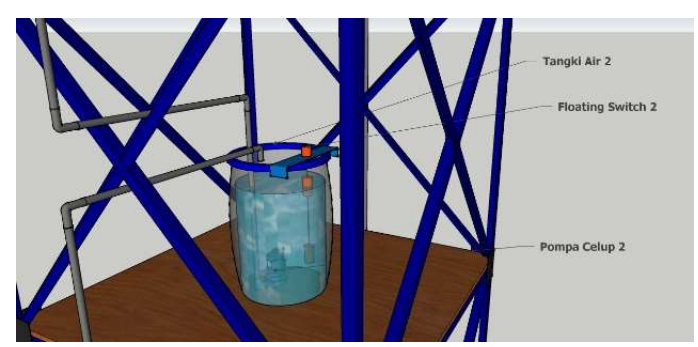

Gambar 6. Desain tangki air 2

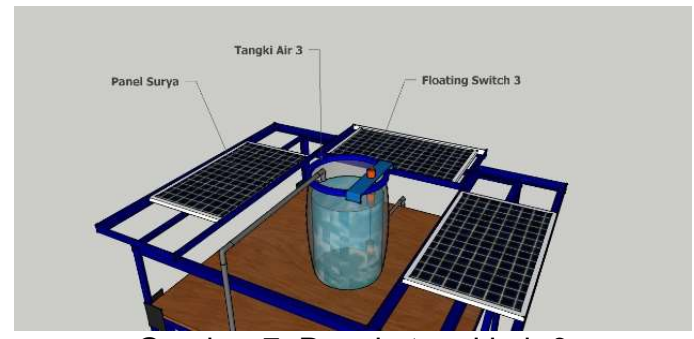

Gambar 7. Desain tangki air 3

Adapun hal-hal yang perlu diperhatikan dalam perancangan unit samping air sungai monitoring kualitas air menggunakan tenaga matahari antara lain:

1. Tutupan Awan/Lama penyinaran

2. Penyinaran Matahari Pada Solar Sel

3. Solar sel

4. Performance Pompa DC

5. Sistem distribusi /Transmisi Air Baku

6. Sistem Penyimpanan/ACCU

7. Pemilhan Sistem Penyimpanan Untuk Panel Surya

8. Sistem kontrol dan otomasi

Faktor yang perlu diperhatikan dalam perakitan unit samping air sungai monitoring kualitas air menggunakan tenaga matahari antara lain :

1. Faktor cuaca mempengaruhi lamanya penyinaran matahari sehingga pengisian daya ke baterai tidak optimal

2. Kontinyuitas dan kemudahan perawatan unit sampling

3. Masih banyaknya pepohonan di area sekitar menara yang dapat mengganggu solar cell

4. Bayangan tangki dapat menutupi solar cell dari sinar matahari, dapat menurunkan kapasitas tangkapan solar cell.

\subsection{Desain Teknologi Online Monitoring Kualitas Air}

Teknologi online monitoring kualitas air adalah sistem pemantauan kualitas air realtime yang menggunakan mainboard komputer sebagai data loggernya.

Komponen Onlimo yang digunakan adalah sebagai berikut :

1. Box panel PVC

2. Battery 2 unit $100 \mathrm{Ah}$

3. Raspberry Pi dengan fan 
4. Cover Raspberry

5. Solar panel 2 unit 150 WP dan 1 unit 50 WP

6. LCD 7 inch

7. Solar charge controller $30 \mathrm{~A}, 12 \mathrm{~V}$

8. LED Matriks $64 \times 16$

9. Adaptor $5 \mathrm{~V}, 5 \mathrm{~A} 2$ buah

10. Rangka

11. Bracket

12. Lock panel

13. CCTV

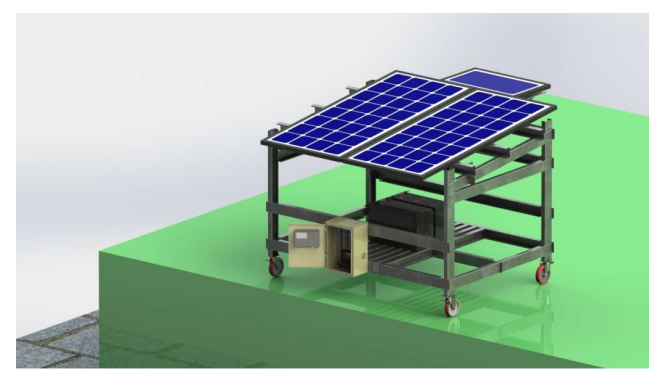

Gambar 8. Desain 3D Teknologi Onlimo (Isometric)

\subsection{Instalasi sistem sampling air tenaga surya dan teknologi online monitoring kualitas air}

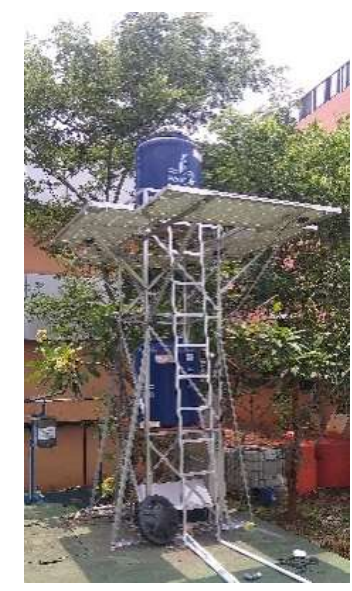

Gambar 9. Sistem sampling air tenaga surya

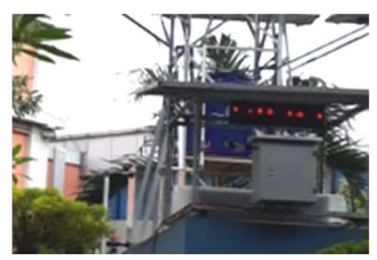

Gambar 10. Teknologi online monitoring kualitas air

\section{KESIMPULAN}

Pada kondisi ideal pada elevasi antara permukaan air antara tangki penampung 1 dan tangki penampung 2 antara $1-5 \mathrm{~m}$ ( elevasi positif), maka sistem pengambilan air baku masih idial menggunakan 1 pompa celup. Namun pada kondisi dimana elevasi permukaan air antara tangki penampung 1 dan tangki penapung 2 berada pada elevasi sama atau negatif dimana elevasi tangki penampung 2 lebih tinggi dari pada elevasi penampung 1 (elevasi maksimum dengan elevasi -6 m), maka harus dirancang menggunakan sistem pompa bertingkat (cascade) (2 pompa celup yang diseri). Kontrol pompa celup seri ke dua dikontrol menggunakan switch apung.

Pada kondisi kemarau alat dapat bekerja optima karena tidak ada masalah dalam pengisian daya ke baterai, sehingga unit beroperasi malam hari tidak mengalami kendala.

\section{DAFTAR PUSTAKA}

1. Heru Dwi Wahjono, dkk. 2015. Buku Sistem Pemantauan Online Untuk Pengendalian Pencemaran Kualitas Air Sungai di DAS Ciliwung. Pusat Teknologi Lingkungan BPPT.

2. Suhendar I. Sachoemar dan Heru Dwi Wahjono. 2007. Kondisi Pencemaran Lingkungan Perairan di Teluk Jakarta. JAI Vol 3 No. 1. 2007. PTL BPPT.

3. Wahjono, Heru Dwi. 2006. Sistem Pemantauan Online (ONLIMO) Kualitas Air dengan Menggunakan Sistem Komunikasi GSM. Jurnal Teknologi Lingkungan Vol. 7 No. 2 Hal. 115-128.

4. Aliyu, Mansur, Hassan, Ghassan. A review of solar-powered water pumping systems. 2018. Saudi Arabia: King Fahd University of Petroleum and Miner.

5. Pali, Bahadur Singh and Shelly Vadhera. 2019. A novel solar photovoltaic system with pumped-water storage for continuous power at constant voltage. Volume 181, 1 February 2019, Pages 133-142. India: Department of Electrical Engineering, National Institute of Technology, Kurukshetra.

6. Research and current status of the solar photovoltaic water pumping system

7. A Novel Water Quality Monitoring System Based on Solar Power Supply \& Wireless Sensor Network. 


\section{Lampiran}

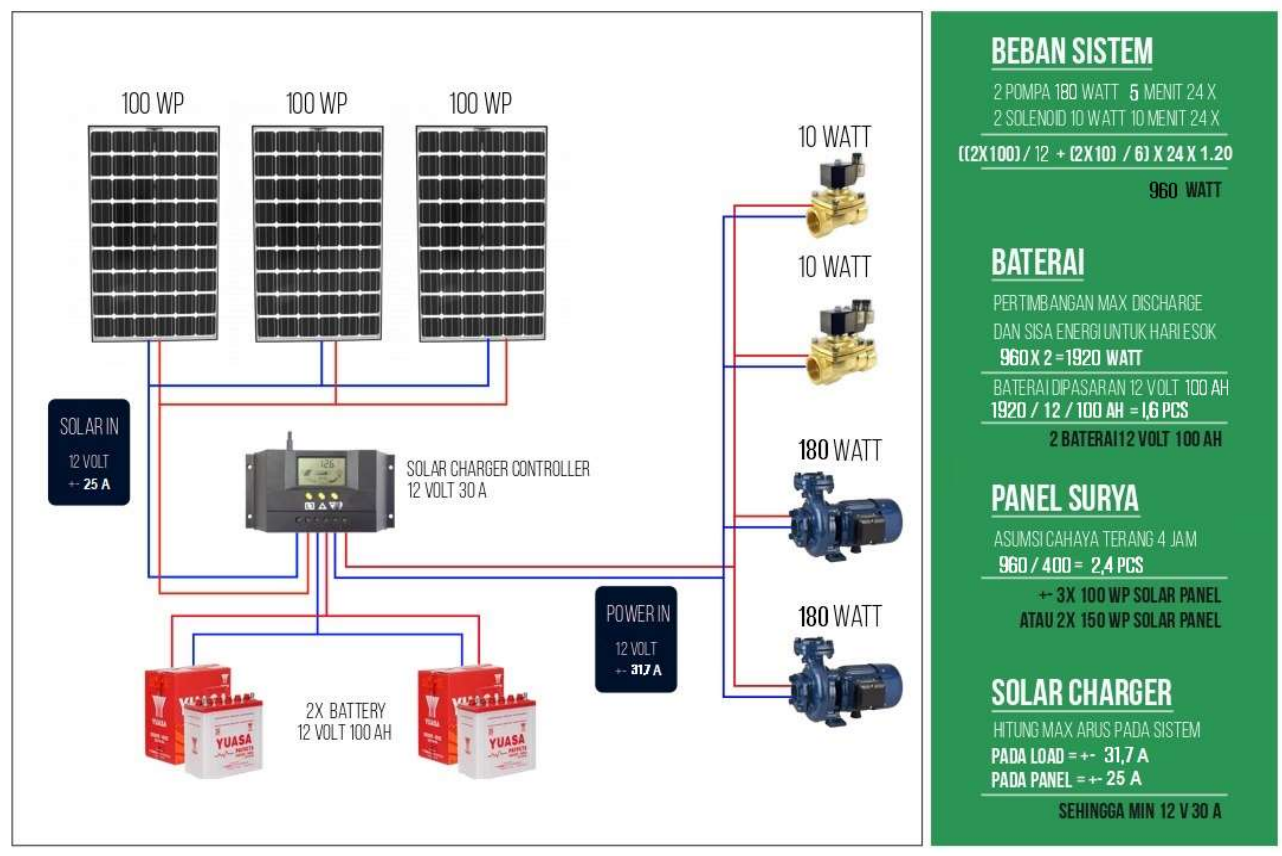

Gambar 11. Diagram perhitungan kebutuhan listrik sistem sampling

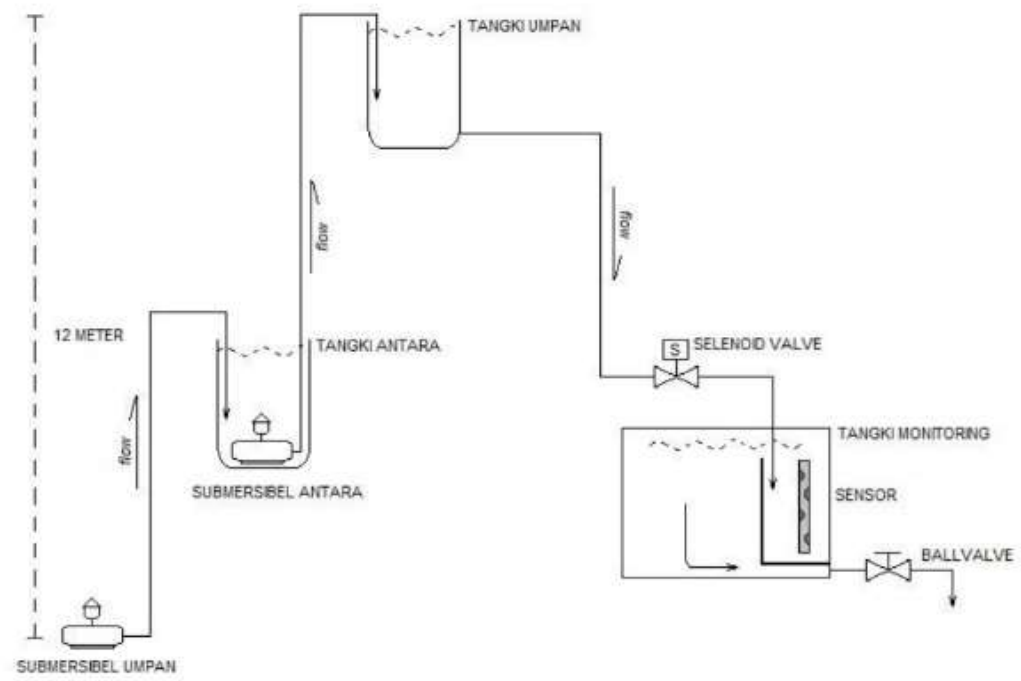

Gambar 12. Flow diagram pengambilan sampel air sungai 


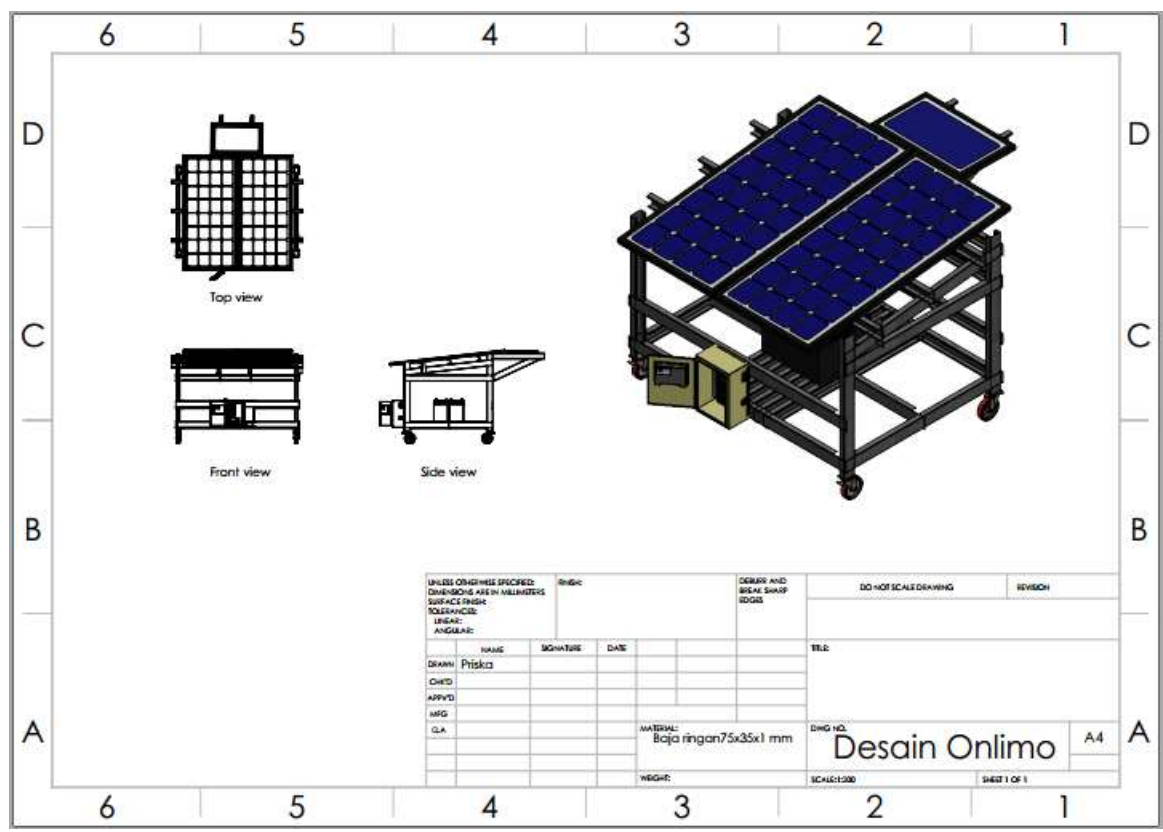

Gambar 13. Desain 3D Onlimo OSS (Gambar Proyeksi)

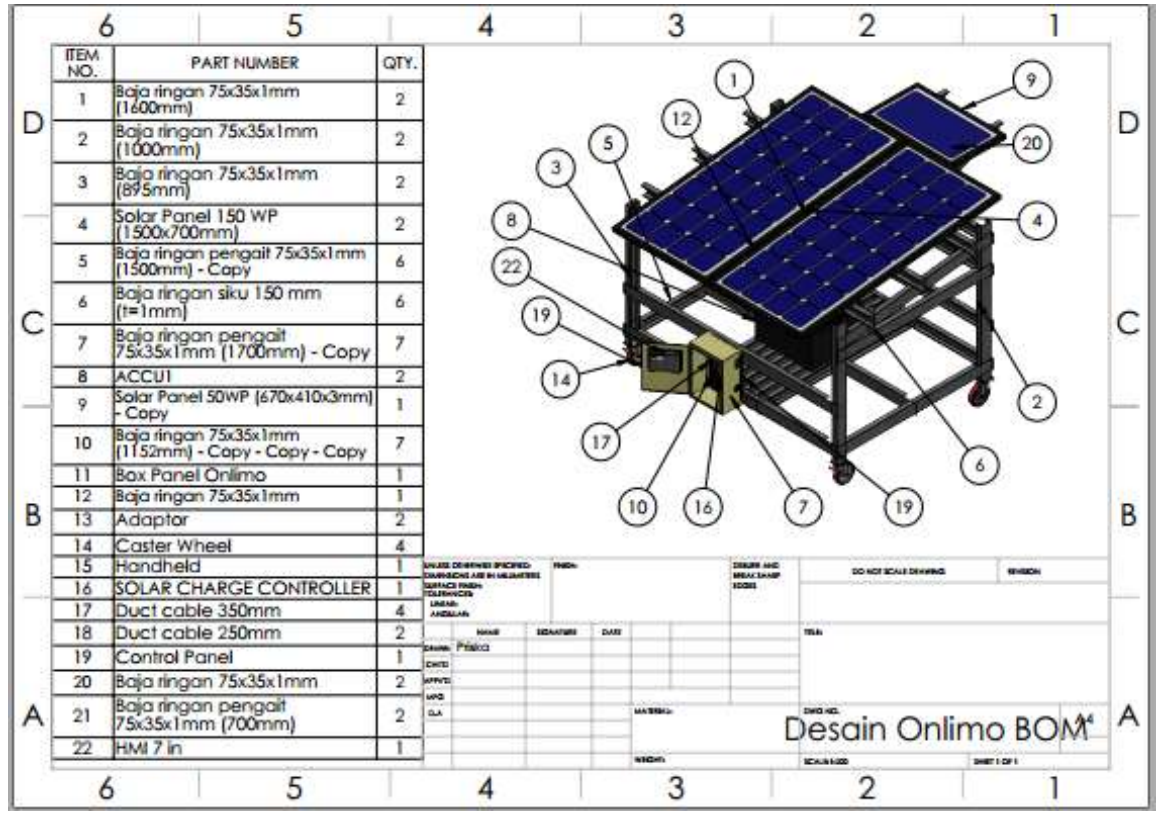

Gambar 14. Desain 3D Onlimo OSS (Bill of Material) 